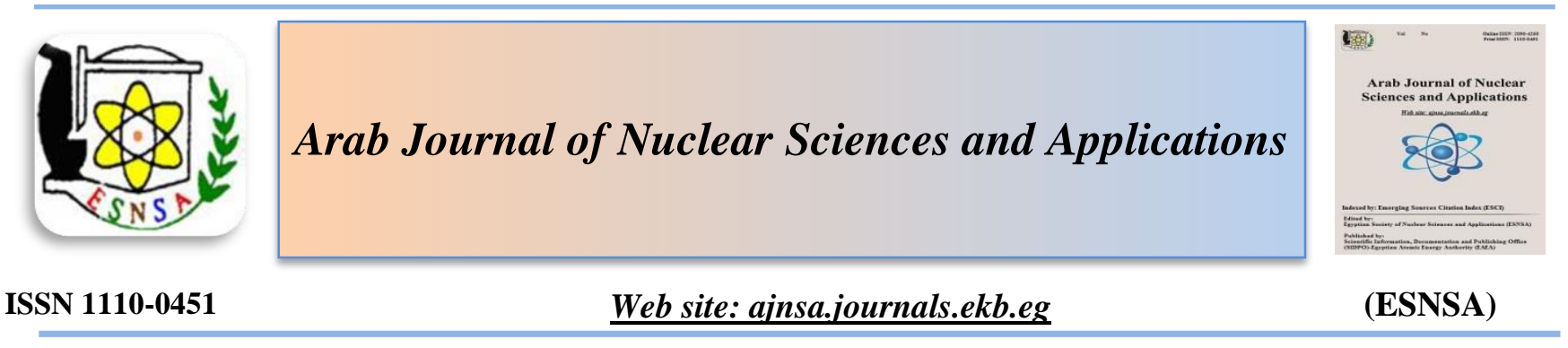

\title{
Evaluating the Radiological Hazards of Contaminated Soil with Naturally Occurring Radioactive Materials (NORM) Resulting from Produced Water during Oil \& Gas Production
}

\author{
O. S.Desouky ${ }^{1}$, T. Morsi' ${ }^{2}$, and S. M. El-Marakby ${ }^{1}$ \\ ${ }^{1}$ Biophysics Lab. , Radiation Physics Department., National Center for Radiation Research and \\ Technology (NCRRT), Egyptian Atomic Energy Authority (EAEA) \\ ${ }^{2}$ Radiation Protection \& Civil Defense Department, Nuclear Research Center, Egyptian Atomic Energy \\ Authority (EAEA)
}

Received 10 Dec 2020 Accepted 31 Dec 2020

\begin{abstract}
Uncontrolled disposal of water extracted during oil and gas production leads to contamination of the surrounding soil with naturally occurring radioactive materials (NORM), resulting in contamination of huge volumes of soil with radium isotopes $\left({ }^{226} \mathrm{Ra}\right.$ and $\left.{ }^{228} \mathrm{Ra}\right)$. In order to assess the radiological health hazards and excess lifetime cancer risks associated with the contaminated soil, the concentration of the naturally occurring radionuclides ${ }^{226} \mathrm{Ra},{ }^{232} \mathrm{Th}$ and ${ }^{40} \mathrm{~K}$ were determined using gamma ray spectrometry. The mean activity concentrations of ${ }^{226} \mathrm{Ra},{ }^{232} \mathrm{Th}$ and ${ }^{40} \mathrm{~K}$ were found to be $1939.56,737.86$ and198.21Bq $\mathrm{kg}^{-1}$, respectively. The results of the radiological indices and annual effective dose $\&$ cancer risk estimated by RESRAD obtained in this study were all higher than their worldwide mean values. This indicates the danger of discharging the produced water resulting from oil and gas production into evaporation ponds without taking preventive measures that limit soil contamination and thus limiting workers' exposure to natural radioactive materials. There is a need to establish clear national rules and regulations for dealing with natural radioactive materials resulting from various oil and gas fields in order to contribute to the control and management policy of technologically enhanced naturally occurring radioactive materials (TE-NORM) released from this industry.
\end{abstract}

Keywords: NORM, RESRAD, Effective Dose, Excess Cancer Risk

\section{Introduction}

Oil \& gas industry has been described as one of the most important industries in the twenty- first century[1] as a major energy and income source in many countries today. With the world's demand for energy constantly rising, the role of oil and gas in supporting social growth has been growing. The daily global consumption of oil grew from 80 million barrels in the year 2000 to 98 million barrels in 2017, indicating that a large quantity of oil and gas is produced every day from traditional and unconventional fields. The main supply stream however is not oil or gas; the world's average production ratio of water and oil is $3: 1$, meaning that approximately 300 million barrels of water are being brought to the surface every day along with oil and gas. Produced water usually contains toxic pollutants, posing a great threat to environment and increasing field cost [2]. In spite of the importance of the petroleum industry, a large quantity of waste was produced especially waste water which accounts about $80 \%$ of liquid waste [3] and more than $95 \%$ in aged oilfields [4]. The oil/water volume ratio is approximately 1:3 [5]. About 300 million

Corresponding author: biophysics65@gmail.com

DOI: 10.21608/ajnsa.2020.53169.1422

(C) Scientific Information, Documentation and Publishing Office (SIDPO)-EAEA 
barrels of water are produced every day from both oil and gas fields, of which more than $40 \%$ of is discharged into the environment.

Most of oil companies worldwide, including companies working in the Middle East, disposed their wastes in unlined wells and lagoons. Over time, the soils of these lagoons become highly contaminated with NORM. Therefore sub-surface contamination is expected with significant degree. Soil remediation should be performed according to the radiation protection principles. Therefore, the polluted soil needs to remove the contamination according to the radiation protection rules [6]. The major components of TE-NORM that accumulates in the oil \& gas production equipment during extraction and processing operations are Radium226 and radium-228 and their progenies (coming from the decay chains of uranium-238 and thorium232 , respectively). Natural uranium and thorium are present in underground formations and stay frequently in place [7]. Co-precipitation of radium with barium sulphate $\left(\mathrm{RaBaSo}_{4}\right)$ or other types of scales is the main source of the water radioactivity. Therefore, the barium ions concentration in produced water may possibly provide a strong indication of radium isotopes in water waste [8]. The environmental pollution and human health risk occurred due to the uncontrolled release of radioactivity associated with TE-NORM levels. The TE-NORM harmful radiation may enter the human body through different pathways, internal contamination such as absorption, inhalation and ingestion or external exposure.

The aim of this study is to assess the radiological risks that workers or even the public may be exposed as a result of soil contamination resulting from oil and gas production. The study was conducted on an evaporation pond in one of the producing oil and gas companies in the Western Desert, Egypt by measuring the specific activity of ${ }^{238} \mathrm{U},{ }^{232} \mathrm{Th} \&^{40} \mathrm{k}$ in the soil in addition to calculating the radiological indices. Also RESRAD Code was used to evaluate the effective dose and cancer risk.

\section{MATERIALS AND METHODS}

\section{Study area}

Samples were collected from the site of one of the petroleum production companies in the Western Desert in Egypt, and the samples were collectedfrom the sediment at the bottom of an old evaporation pond for the produced water during oil extraction. A total of twenty samples were collected during site remediation from the contaminated soil by one of the licensed companies.

Gamma Spectrometric Analysis \& Calibration of Hyper Purity Germanium detector

As shown in Figures ( 1 \&2) the energy and efficiency calibrations for the Hyper Purity Germanium detector carried out using IAEA-RGU1 reference material with an activity concentration of $4940 \mathrm{~Bq} / \mathrm{kg}$, which has been prepared by the Canadian Center for Mineral and Energy Technology on behalf of the International Atomic Energy Agency.

The prepared 20 samples were counted using the HPGe detector with a relative efficiency of $25 \%$. Efficiency calibration was determined using uranium ore. The correlation between energy to channel number was $0.5 \mathrm{keV} / \mathrm{channel}$. The gamma-ray spectrum was analyzed using Genie 2000, which measures the activity concentration of the samples. An amount of 0.5 $\mathrm{kg}$ of NORM samples was packed in a plastic container, sealed and stored for 4 weeks to establish the secular equilibrium between the natural radionuclides and their respective progenies. The measuring counting time was 4hrs. The natural background radiation was subtracted from the accumulated spectrum. The activity levels of ${ }^{226} \mathrm{Ra}$ and ${ }^{232} \mathrm{Th}$ were determined by their decay products ${ }^{214} \mathrm{Bi}(609 \mathrm{keV}$ and $1120 \mathrm{keV}),{ }^{214} \mathrm{~Pb}(295$ $\mathrm{keV}$ and $352 \mathrm{keV})$ and ${ }^{228} \mathrm{Ac}(338 \mathrm{keV}$ and 911 $\mathrm{keV}$ ), respectively, while the activity of ${ }^{40} \mathrm{~K}$ was determined from its $1460.8 \mathrm{keV}$ gamma energy [9].

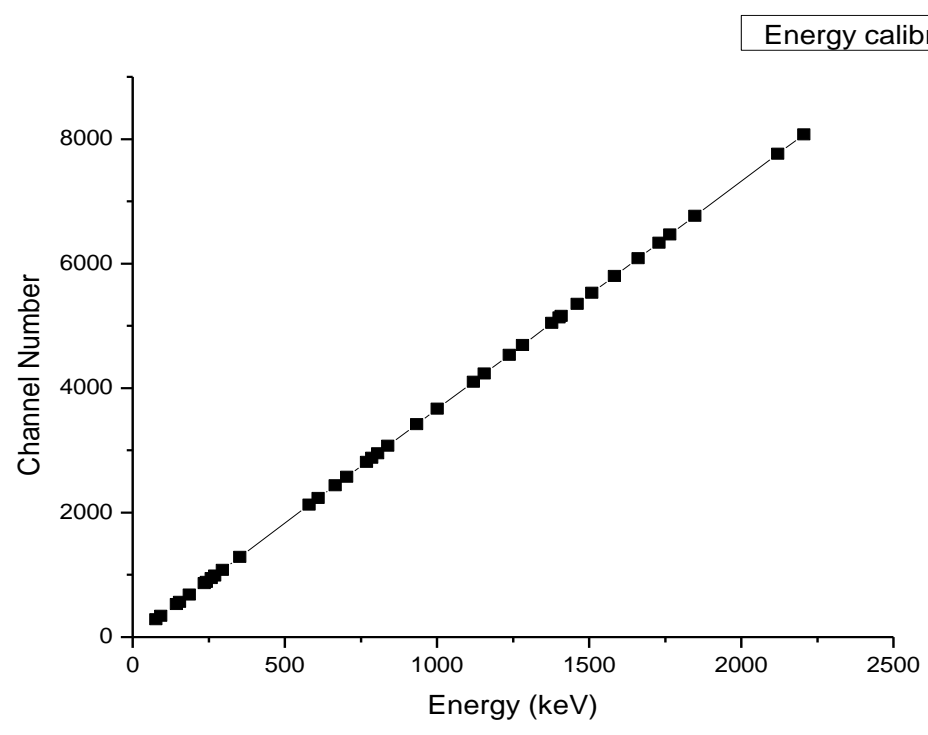

Fig. (1): Energy calibration for high purity germanium detector

Arab J. Nucl. Sci. \& Applic. Vol. 54, No.1 (2021) 


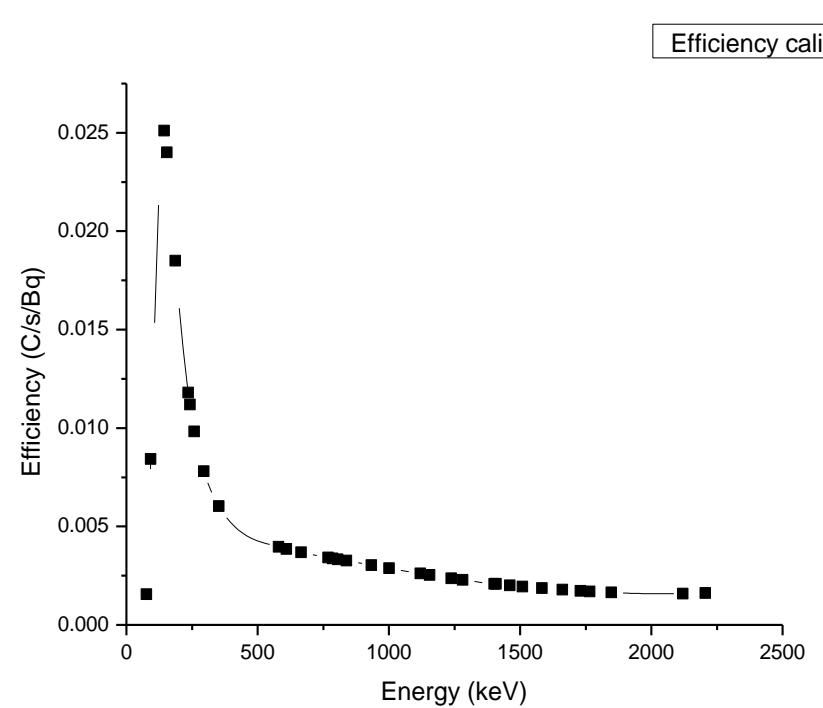

Fig.(2): Efficiency calibration for high purity germanium detector

\section{RESRAD Code}

In order to assess the contaminated evaporation pond, a software tool developed by the US Department of Energy was used. The RESRAD computer code version 7.0 was used to evaluate the effective dose equivalent for all pathway exposure to radionuclides ${ }^{226} \mathrm{Ra},{ }^{232} \mathrm{Th}$ and ${ }^{40} \mathrm{~K}$ and excess cancer risk to workers exposed to evaporation pond. The effective dose is the sum of the weighted equivalent doses in all tissues and organs of the body. The dose and risk assessment was performed for the contaminated evaporation pond area of 5000 $\mathrm{m}^{2}$ with thickness of $0.1 \mathrm{~m}$, and an uncontaminated unsaturated zone thickness of $4 \mathrm{~m}$. The Exposure duration for the workers was considered to be 30 years. The outdoor time fraction is 0.25 , and indoor time fraction is 0.5 . All other remaining input values for RESRAD were taken from available default data in a previously reported model [10].

\section{Results and Discussion}

Radiation exposure from NORM can occur in seven environmental pathways, a major pathway of them involves oil and gas extraction. These pathways include radon inhalation, external gamma exposure, groundwater intake, absorption of superficial water, inhalation of the dust, ingestion of food and skin beta exposure [11]. The pathways of greatest concern for oilfield workers are exposure to external gamma ray, dust inhalation and skin beta exposure. External exposure source occurs when, first the concentration of NORM within equipment is high enough so that gamma rays penetrate the equipment walls and second, polluted scale and sludge are extracted from the equipment [12]. Produced water is considered to be one of the largest volumes of oil \& gas industry waste containing NORM; it is usually separated from oil and injected in the disposal wells. In the past, several oil companies have been conducting unregulated disposal of extracted water for a number of years. Unlined artificial evaporation ponds have stored generated water. These ponds have become highly polluted with TE-NORM resulting in contamination with radionuclides and the environmental radiation pollution [13].

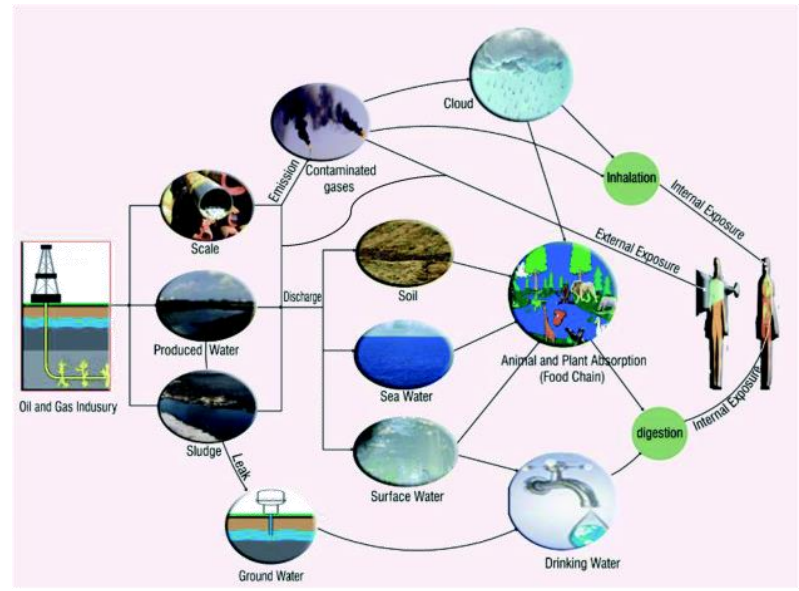

Fig. (3): The main forms of petroleum pollution of TENORM [14]

Activity concentrations of ${ }^{238} \mathrm{U},{ }^{232} \mathrm{Th}$ and ${ }^{40} \mathrm{~K}$ The activity concentrations of ${ }^{226} \mathrm{Ra},{ }^{232} \mathrm{Th}$ and ${ }^{40} \mathrm{~K}$ in the measured soil of the evaporation pond vary from 678 to 3599,222 to 1700 and 100 to $337 \mathrm{~Bq}$ $\mathrm{kg}^{-1}$ with average values of $1939.56,737.86$ and $198.21 \mathrm{~Bq} \mathrm{~kg}^{-1}$ respectively as shown in Table (1). It is obvious that the previous average activity concentrations of ${ }^{226} \mathrm{Ra},{ }^{232} \mathrm{Th}$ and ${ }^{40} \mathrm{~K}$ are higher than world's average concentration of these radionuclides which is 25,25 and $370 \mathrm{~Bq} \mathrm{~kg}^{-1}$ respectively as per UNSCEAR Report,1988 [15].

\section{Radium equivalent $\left(R a_{e q}\right)$}

The radiation risks of contaminated soil are measured by evaluating the total effect of ${ }^{226} \mathrm{Ra}$, ${ }^{232} \mathrm{Th}$ and ${ }^{40} \mathrm{~K}$ as the radium equivalent activity in soil $\left(\mathrm{Ra}_{\mathrm{eq}}\right)$. The $\mathrm{Ra}_{\mathrm{eq}}$ represents the weighted sum of the activities of ${ }^{226} \mathrm{Ra},{ }^{232} \mathrm{Th}$ and ${ }^{40} \mathrm{~K}$ 
activities in a soil content. It is based on the assumption that $370 \mathrm{~Bq} \mathrm{~kg}^{1}{ }^{1}$ of ${ }^{226} \mathrm{Ra}, 259 \mathrm{~Bq}$ $\mathrm{kg}^{-1}$ of ${ }^{232} \mathrm{Th}$, and $4810 \mathrm{~Bq} \mathrm{~kg}^{1}$ of ${ }^{40} \mathrm{~K}$ produce the same $\square$-radiation dose rate. The Radium equivalent index $\left(\mathrm{Ra}_{\mathrm{eq}}\right)$ in $\mathrm{Bq} / \mathrm{kg}$ is calculated using the following formula [16]:

$$
\mathrm{Ra}_{\mathrm{eq}}=\mathrm{A}_{\mathrm{Ra}}+1.43 \mathrm{~A}_{\mathrm{Th}}+0.077 \mathrm{~A}_{\mathrm{K}}
$$

Where, $A_{T h}, A_{R a}$ and $A_{K}$ are the mean activity of the ${ }^{232} \mathrm{Th},{ }^{226} \mathrm{Ra}$ and ${ }^{40} \mathrm{~K}(\mathrm{~Bq} / \mathrm{Kg})$ in the samples respectively.

The equation of radium equivalent is based on the postulation that $370 \mathrm{~Bq} \mathrm{~kg}^{-1}$ of ${ }^{226} \mathrm{Ra}, 259 \mathrm{~Bq} \mathrm{~kg}^{-1}$ of ${ }^{232} \mathrm{Th}$, and $4810 \mathrm{~Bq} \mathrm{~kg}^{-1}$ of ${ }^{40} \mathrm{~K}$ generate the same gamma-ray dose rate. Radium equivalents parameters have also been defined to compare the levels of radioactivities of ${ }^{226} \mathrm{Ra},{ }^{232} \mathrm{Th}$ and ${ }^{40} \mathrm{~K}$, as the radiation is not uniformly distributed across both the soil and sediment. The corresponding radium is related to the external gamma dose as well as the internal alpha particles of radon and its descendants. The acceptable maximum value of the radium equivalent activity is $370 \mathrm{~Bq} \mathrm{~kg}$, which corresponds to an effective dose of $1 \mathrm{mSv} \mathrm{yr}^{-1}$ for to the population of the dwellings [17].

The values of the $\left(\mathrm{Ra}_{\mathrm{eq}}\right)$ calculated for the contaminated soil samples ranged from 1020 to $6040 \mathrm{~Bq} \mathrm{~kg}{ }^{1}$ with an average of $3031 \mathrm{~Bq} \mathrm{~kg}^{-1}$ (Table.1).It can be seen that the average value of $\mathrm{Ra}_{\text {eq }}$ for the soil in the study area is eight times higher than the safe limit of $370 \mathrm{~Bq} \mathrm{~kg}^{-1}$ [18].

\section{Evaluation of radiological hazard effects}

Absorbed dose rate $(D)$

Tissue and/or organ radiation injure is dependent on the dose of radiation received or on the absorbed dose. The energy given by the unit mass of the irradiated substance shall be the absorbed radiation dose. Conversion factors $0.462,0.604$ and 0.0417 for uranium, thorium or potassium respectively [17] are used to translate the determined activity levels doses.

$$
\mathrm{D}(\mathrm{nGy} / \mathrm{h})=0.462 \mathrm{~A}_{\mathrm{U}}+0.604 \mathrm{~A}_{\mathrm{Th}}+0.041 \mathrm{~A}_{\mathrm{k}}
$$

Where, $A_{k}, A_{U}$ and $A_{T h}$ are the activity concentrations of ${ }^{40} \mathrm{~K},{ }^{238} \mathrm{U}$ and ${ }^{232} \mathrm{Th}$ in $\mathrm{Bqkg}^{-1}$ respectively. In areas with gamma radiation from series ${ }^{238} \mathrm{U},{ }^{232} \mathrm{Th} \quad{ }^{40} \mathrm{~K}$ and their respective progenies, the appropriate total absorbed dose should not exceed $0.0509 \mathrm{mGy} / \mathrm{h}$ [17]. The external outdoor doses $\left(D_{\text {out }}\right)$ were estimated to range from 307 to $1640 \mathrm{nGy} \mathrm{h}^{-1}$ with an average value of $85.55 \mathrm{nGy} \mathrm{h}^{-1}$ due to the presence of ${ }^{226} \mathrm{Ra},{ }^{222} \mathrm{Th}$ and ${ }^{40} \mathrm{~K}$ in the evaporation pond soil (Table 1). The average is higher than the worlds' average of $59 \mathrm{nGy} \mathrm{h}^{-1}$ as per UNSCEAR Report, 2000[17]. Whereas the values of $\left(D_{i n}\right)$ calculated during this study ranged from 88.9 to 5200 with an average of $2631.54 \mathrm{nGy} \mathrm{h}^{-1}$, which is higher than the world's average of $84 \mathrm{nGy}$ $\mathrm{h}^{-1}$ as per UNSCEAR Report, 2000[17].

\section{Annual effective dose equivalent (AEDE)}

In all media in the world, including the humans, naturally occurring primordial radionuclides exist to varying degrees. The human body external radiation is primarily due to gamma radiation emitting from the ${ }^{238} \mathrm{U}$ and ${ }^{232} \mathrm{Th}$ series and from ${ }^{40} \mathrm{~K}$ present in all soils. Similarly, indoor exposure to gamma rays, mainly determined by the materials of construction, is inherently greater than outdoor exposure if the earth materials have been used. When the duration of occupancy is taken into account, indoor exposure becomes even more significant [17]. By applying a dose conversion factor of $0.7 \mathrm{~Sv} /$ Gy to the absorbed dose rate "D" 1 $\mathrm{m}$ aboveground, the outdoor annual effective dose equivalent in $\mathrm{mSvy}^{-1}(\mathrm{AEDE}$ in Eq. 3) can be calculated. The expression for $\mathrm{D}$ is described by Eq. $1[17,19]$ :

$$
\begin{aligned}
& \mathrm{AEDE}_{\text {(outdoor) }}\left(\mathrm{mSvy}^{-1}\right)=\mathrm{D}\left(\mathrm{nGyh}^{-1}\right) \times 8760 \mathrm{~h} / \mathrm{y} \times \\
& 0.7 \mathrm{~Sv} / \mathrm{Gy} \times 0.2 \\
& \mathrm{AEDE}_{\text {(indoor) }}\left(\mathrm{mSvy}^{-1}\right)=\mathrm{D}\left(\mathrm{nGyh}^{-1}\right) \times 8760 \mathrm{~h} / \mathrm{y} \times \\
& 0.7 \mathrm{~Sv} / \mathrm{Gy} \times 0.8
\end{aligned}
$$

The global average annual effective dose is $0.4 \mathrm{mSv}$ based on $0.2 \& 0.8$ occupancy factor for outdoor and indoor respectively and $0.7 \mathrm{SvGy}^{-1}$ conversion factor for the absorbed dose in air representing the effective dose received by adult [17].

The annual outdoor effective dose $\left(\mathrm{E}_{\text {out }}\right)$ is estimated from the outdoor external dose rate $\left(\mathrm{D}_{\text {out }}\right)$, time of stay in the outdoor or occupancy factor $(\mathrm{OF}=20 \%$ of $8760 \mathrm{~h}$ in a year) and the conversion factor $(\mathrm{CF}=$ $0.7 \mathrm{~Sv} \mathrm{~Gy}^{-1}$ ) to convert the absorbed dose in air to effective dose. The annual effective dose for the outdoor situation calculated from the absorbed dose rate in the study area was found to be varying from 0.37 to 2.02 with an average value of $1.05 \mathrm{mSv}^{-1}$. 
This was found to be nearly double the natural background gamma level $0.41 \mathrm{mSv} \mathrm{y}^{-1}$ for normal background areas. Whereas the annual effective dose for indoor ranged from 4.36 to 25.5 with an average value of 12.91 and the average of the total annual effective dose is $13.96 \mathrm{mSv} / \mathrm{y}$. It is clear that the values of workers annual external effective dose in NORM contaminated areas in oil and gas production sites show that the external dose depends on the activity concentrations of the NORM contamination (The higher the activity, the higher the annual external effective dose equivalent).

\section{Hazard indices $\left(H_{\text {ex }}\right.$ and $\left.H_{\text {in }}\right)$}

Two other indices that represent external and internal radiation hazards were described by Beretka and Mathew [16]. External hazard index $\mathrm{H}_{\mathrm{ex}}$ and internal hazard index $\mathrm{H}_{\mathrm{in}}$ are used to evaluate external exposure to gamma radiation in outdoor air and internal exposure to radon respectively. The external and internal hazard indices are derived from $\mathrm{Ra}_{\text {eq }}$ expression through the assumption that its allowed maximum value (equal to unity) corresponds to the upper limit of $\mathrm{Ra}_{\text {eq }}\left(370 \mathrm{~Bq} \mathrm{~kg}^{-1}\right)$. The external hazard index $\left(H_{\mathrm{ex}}\right)$ and internal hazard index $\left(H_{\text {in }}\right)$ can then be defined as

$\mathrm{H}_{\mathrm{ex}}=\left(\mathrm{A}_{\mathrm{Ra}} / 370 \mathrm{Bqkg}^{-1}\right)+\left(\mathrm{A}_{\mathrm{Th}} / 259 \mathrm{Bqkg}^{-1}\right)+($ $\left.\mathrm{A}_{\mathrm{K}} / 4810 \mathrm{Bqkg}^{-1}\right)$

$\mathrm{H}_{\mathrm{in}}=\left(\mathrm{A}_{\mathrm{U}} / 185 \mathrm{Bqkg}^{-1}\right)+\left(\mathrm{A}_{\mathrm{Th}} / 259 \mathrm{Bqkg}^{-1}\right)+($ $\left.\mathrm{A}_{\mathrm{K}} / 4810 \mathrm{Bqkg}^{-1}\right)$

Where, $\mathrm{A}_{\mathrm{Ra}}, \mathrm{A}_{\mathrm{Th}}$ and $\mathrm{A}_{\mathrm{K}}$ are the activity concentrations of ${ }^{226} \mathrm{Ra},{ }^{232} \mathrm{Th}$ and ${ }^{40} \mathrm{~K}$, respectively. The external and internal hazard indices should be less than unity for radiological safety protection. Areas with indices higher than unity may pose a significant radiological health risk to the workers and inhabitants due to exposure to ionizing radiation from the natural radionuclides in the soil.

The external hazard index $\left(H_{\mathrm{ex}}\right)$ calculated in the current study varies from 2.75 to 16.4 and the $H_{\text {in }}$ ranged 4.5 to 26 . The average values of the $H_{\mathrm{ex}}$ and $\mathrm{H}_{\text {in }}$ are 8.21 and 13.47 respectively which must be kept less than unity for the radiation exposure to be insignificant.

\section{Excess Lifetime Cancer Risk (ELCR)}

The probability of excess life cancer is the possibility that cancer will grow at a certain level of exposure over lifetime. A higher value of ELCER means that the person exposed has a higher risk of induction of cancer. It can be calculated using the following formula [20]:

$\mathrm{ELCER}=\mathrm{AEDE} \times \mathrm{DL} \times \mathrm{RF}$

$\mathrm{AEDE}=$ Annual Effective Dose Equivalent, $\mathrm{DL}=$ Duration of Life (estimated to be 70years) and RF = Risk Factor $\left(\mathrm{Sv}^{-1}\right)$. For stochastic effects, ICRP uses $\mathrm{RF}$ as 0.05 for the general public. World permissible standard of $0.290 \times 10^{-3}$.The results show that $E L_{C R}$ out and ELCR $_{\text {in }}$ average are 3.69 and 45.18 respectively, whereas the total ELCR is 48.87 . The world average value for ELCR is $0.29 \times 10^{-3}$ which clearly shows that the ELCR values from the soil samples in the present study are higher than the world average value.

Many international organizations accept that even lower levels of ionizing radiation will raise the risk of cancer. A higher dose of radiation raises the risk of cancer. Exposure to one Sievert of radiation spread out over time is expected to increase the lifetime risk of fatal cancer in an average adult by around $4 \%$ and a $0.8 \%$ chance of hereditary defect in prospect progeny [21].

\section{5) Annual Gonadal Equivalent Dose (AGED)}

The most sensitive organs to radiation are gonads, the bone marrow and the bone surface cells as reported by UNSCEAR (2000). An increase in AGED has been known to affect the bone marrow, causing destruction of the red blood cells that are then replaced by white blood cells. This situation results in a blood cancer called leukemia which is fatal. The annual gonadal dose equivalent (AGDE) due to the specific activities of ${ }^{226} \mathrm{Ra},{ }^{232} \mathrm{Th}$ and ${ }^{40} \mathrm{~K}$ was calculated using the following relation [22].The world average in soils is $300 \mu \mathrm{Sv} /$ year [23].

$\operatorname{AGED}(\mathrm{mSv} / \mathrm{yr})=3.09 \mathrm{~A}_{\mathrm{Ra}}+4.18 \mathrm{~A}_{\mathrm{Th}}+0.314 \mathrm{~A}_{\mathrm{K}}(8)$

The human gonads have been found to be remarkable as the weighting factor is 0.20 , the highest in the body compared to the values 0.12 (red marrow, column, lung and stomach), 0.05 (bladder, breasts, liver and oesophagus) and 0.01 (skin and bone surface) [24]. With a mean value of 9.21 $\mathrm{mSv} / \mathrm{y}$, AGED ranged from 3.1 to $18.3 \mathrm{mSv} / \mathrm{y}$. The dose exposure to gonads in the study areas considered greater than the global value of 300 $\mu \mathrm{Sv} /$ year was attributed primarily to gamma radiation exposure from uranium-enriched soils [25]. 
Table (1). Results of activity concentrations $(\mathrm{Bq} / \mathrm{Kg})$

\begin{tabular}{ccccc}
\hline Radionuclides & $\begin{array}{c}\text { Minimum } \\
\left(\mathrm{BqKg}^{-1}\right)\end{array}$ & $\begin{array}{c}\text { Maximum } \\
\left(\mathrm{BqKg}^{-1}\right)\end{array}$ & $\begin{array}{c}\text { AVG. } \\
\left(\mathrm{BqKg}^{-1}\right)\end{array}$ & S.D. \\
\hline $\mathbf{R a}^{226}$ & $\mathbf{6 7 7 . 9 8}$ & $\mathbf{3 5 9 9 . 4 0}$ & 1939.56 & \pm 997.46 \\
$\mathbf{K}^{40}$ & 101.10 & $\mathbf{3 3 7 . 0 0}$ & 198.21 & $\pm \mathbf{8 0 . 5 2}$ \\
$\mathbf{T h}^{232}$ & 222.30 & 1697.50 & 737.86 & \pm 410.94 \\
$\mathbf{R a}_{\text {eq }}$ & $\mathbf{1 0 1 5 . 3 3}$ & $\mathbf{6 0 4 0 . 4 4}$ & $\mathbf{3 0 3 1 . 9 0}$ & $\pm \mathbf{1 6 2 5 . 0 5}$ \\
\hline
\end{tabular}

The alpha $I_{\square \square}$ \&gamma index $I$

The alpha activity of TE-NORM residue requires calculations of the alpha index which represents the internal hazard. Inhalation of radioactive radon gas $\left({ }^{222} \mathrm{Rn}\right)$ originating from the materials requires calculating a representative index to assess the radon exposure. This index is the $\mathrm{I}_{\square \square}$ which can be calculated by the following equation [26-27]:

$\mathrm{I}_{\square}=\mathrm{A}_{\mathrm{Ra}} / 200 \mathrm{~Bq} / \mathrm{kg} \leq 1$

Where, $A_{R a}$ is the activity concentration of ${ }^{226} \mathrm{Ra}$ $(\mathrm{Bq} / \mathrm{kg})$ at the equilibrium with its daughters $\left({ }^{214} \mathrm{~Pb}\right.$ and ${ }^{214} \mathrm{Bi}$ ).

The safe use of any NORM or TE-NORM materials requires $\mathrm{I}_{\square}$ to be less than unity [28].

The representative level index $\mathbf{I}_{\square}$ of the samples is another parameter to estimate the level of gamma radiation hazard associated with the natural radionuclides.

$$
\mathrm{I}_{\square}=\mathrm{A}_{\mathrm{Ra}} / 150+\mathrm{A}_{\mathrm{Th}} / 100+\mathrm{A}_{\mathrm{K}} / 1500
$$

Where, $A_{R a}, A_{T h}$ and $A_{K}$ are the activity concentrations of ${ }^{226} \mathrm{Ra},{ }^{232} \mathrm{Th}$ and ${ }^{40} \mathrm{~K}$, respectively, in $\mathrm{Bq} / \mathrm{kg}$.

Effective dose rate $\left(D_{\text {organ }}\right)$ to different body organs and tissues

The following equation can be used to calculate the effective dose rate delivered to a particular organ [29]:

$$
D_{\text {organ }}\left(\mathrm{mSv} \mathrm{yr}^{-1}\right)=\operatorname{AEDE} * f
$$

Where, $f$ is the conversion factor of organ dose from air dose. The average values of $f$ for various organs and tissues are given in Figure (4). Using these $f$ values, $D_{\text {organ }}$ was calculated by applying Eq. (11) [30].
It has been found that the $\mathrm{I} \gamma \& \mathrm{I} \alpha$ average values are 20.6 and 9.76. The value of radiation hazard parameters in the study area exceeds the recommended limit, which is due to the presence of relatively higher activity concentrations of natural radionuclides in the soil resulting from the produced water.

The RESRAD CODE was used to estimate the contamination via different pathways due to all nuclides (Figures 5\&6) from the soil of the evaporation pond and the consequential the total summed effective doses received by the critical group (Figure 7). Similarly, the trend of the estimated excess cancer risk was performed as shown in Figure (8).

\section{Conclusion}

In conclusion, it could be found that by measuring the radioactivity of the polluted soil in the studied evaporation pond, and through the calculations of radiological hazards indices, as well as through the use of RESRAD Code, the average value of radioactivity of ${ }^{226} \mathrm{Ra},{ }^{232} \mathrm{Th} \&{ }^{40} \mathrm{k}$ and the assessed radiation hazard parameters were found to be exceeding the world safety limit set by the UNSCEAR. Therefore, the radiation protection rules must be applied by protecting the workers present in this place. It is also recommended that the radioactive contamination in the evaporation pond of the studied area should be removed. The study also recommends controlling the produced water extracted during oil and gas production by injecting it into old wells or through discharge in line pits to prevent soil contamination. There is a need to establish clear national rules and regulations for dealing with natural radioactive materials resulting from various oil and gas fields in order to contribute to the control and management policy of TE-NORM released from this industry.

Arab J. Nucl. Sci. \& Applic. Vol. 54, No.1 (2021) 
Table (2): The radiation exposure dose and estimated radiological hazard indices

\begin{tabular}{|c|c|c|c|c|}
\hline & Minimum & Maximum & AVG. & S.D. \\
\hline$D_{\text {out }}(\mathrm{nGy} / \mathbf{h})$ & 306.92 & 1644.93 & 859.55 & \pm 451.89 \\
\hline$D_{\text {in }}(\mathbf{n G y / h})$ & 889.10 & 5195.59 & 2631.54 & \pm 1405.25 \\
\hline $\operatorname{AEDE}_{\text {out }}(\mathrm{mSv} / \mathrm{y})$ & 0.38 & 2.02 & 1.05 & \pm 0.554 \\
\hline $\operatorname{AEDE}_{\text {in }}(\mathbf{m S v} / \mathbf{y})$ & 4.36 & 25.49 & 12.91 & \pm 6.89 \\
\hline $\operatorname{AEDE}_{\text {total }}(\mathrm{mSv} / \mathrm{y})$ & 4.74 & 27.42 & 13.96 & \pm 7.44 \\
\hline AGDE (mSv/y) & 3.10 & 18.28 & 9.21 & \pm 4.92 \\
\hline AUI (mSv/y) & 8.97 & 53.78 & 27.05 & \pm 14.58 \\
\hline $\mathbf{E L C R}_{\text {out }}$ & 2.28 & 7.06 & 3.69 & \pm 1.94 \\
\hline $\mathbf{E L C R}_{\text {in }}$ & 26.48 & 89.21 & 45.18 & \pm 24.13 \\
\hline $\mathbf{E L C R}_{\text {total }}$ & 16.58 & 95.98 & 48.87 & \pm 26.06 \\
\hline $\mathbf{H}_{\text {ex }}$ & 2.75 & 16.35 & 8.21 & \pm 4.40 \\
\hline $\mathbf{H}_{\text {in }}$ & 4.58 & 26.05 & 13.47 & \pm 7.19 \\
\hline $\mathbf{I} \square$ & 6.91 & 41.11 & 20.60 & \pm 11.03 \\
\hline $\mathbf{I}_{\square}$ & 3.39 & 18.80 & 9.76 & \pm 5.20 \\
\hline
\end{tabular}

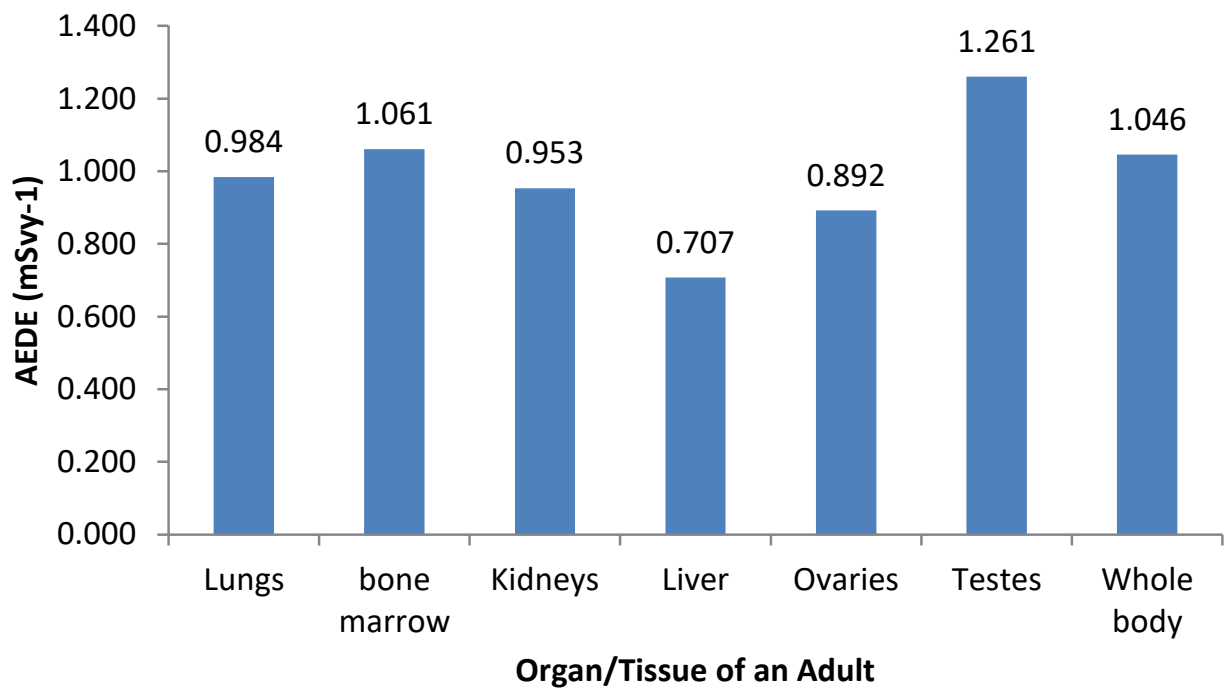

Fig.(4):Annual Effective dose rate $\left(\mathrm{mSvy}^{-1}\right)$ to different organs/tissues 

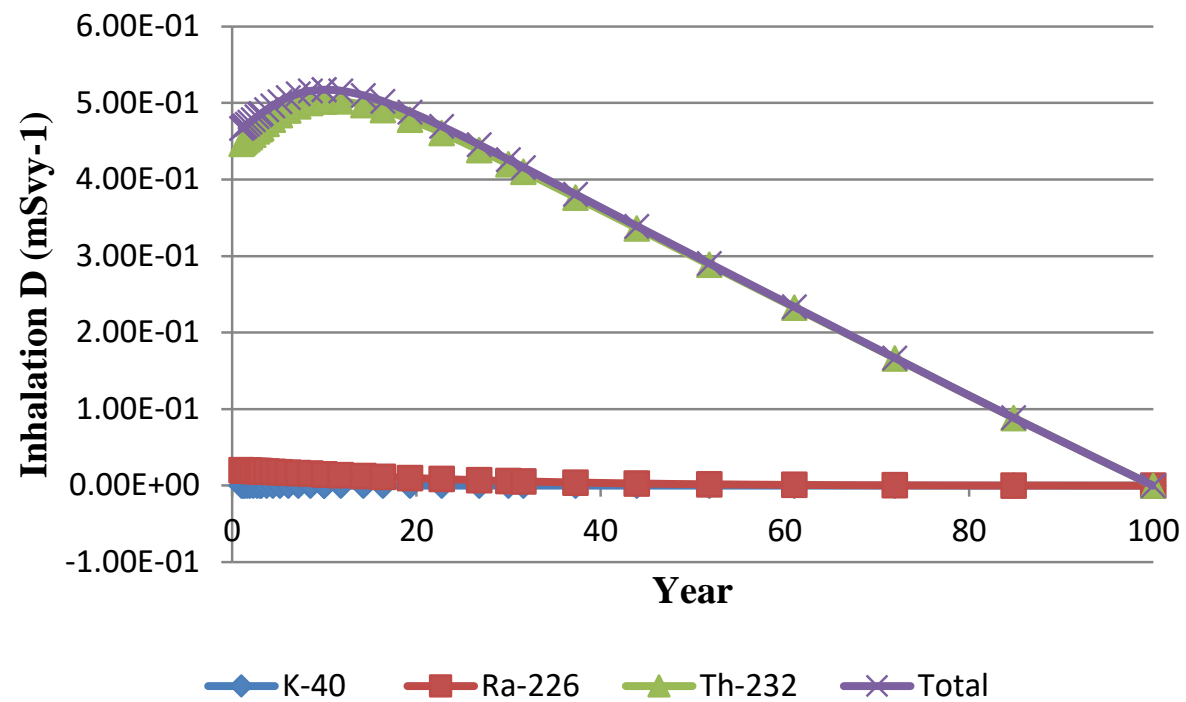

Fig (5). Summed total dose due inhalation of all nuclides
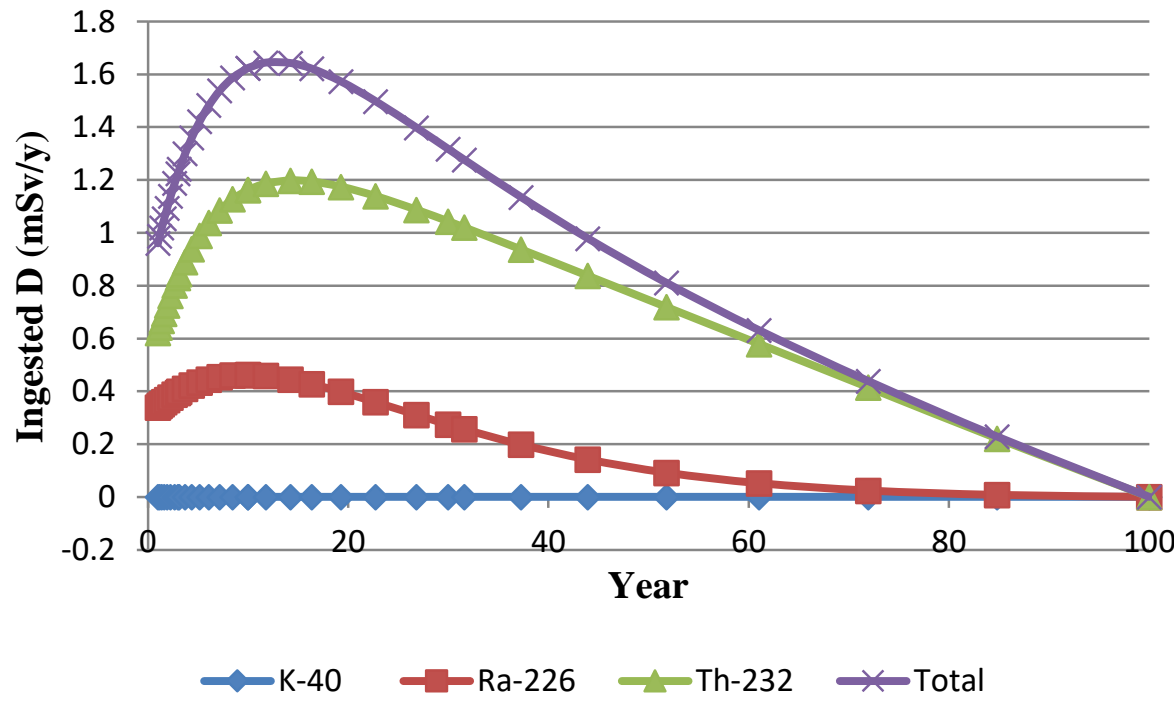

Fig (6): Summed total dose due to all nuclides via ingestion pathway 

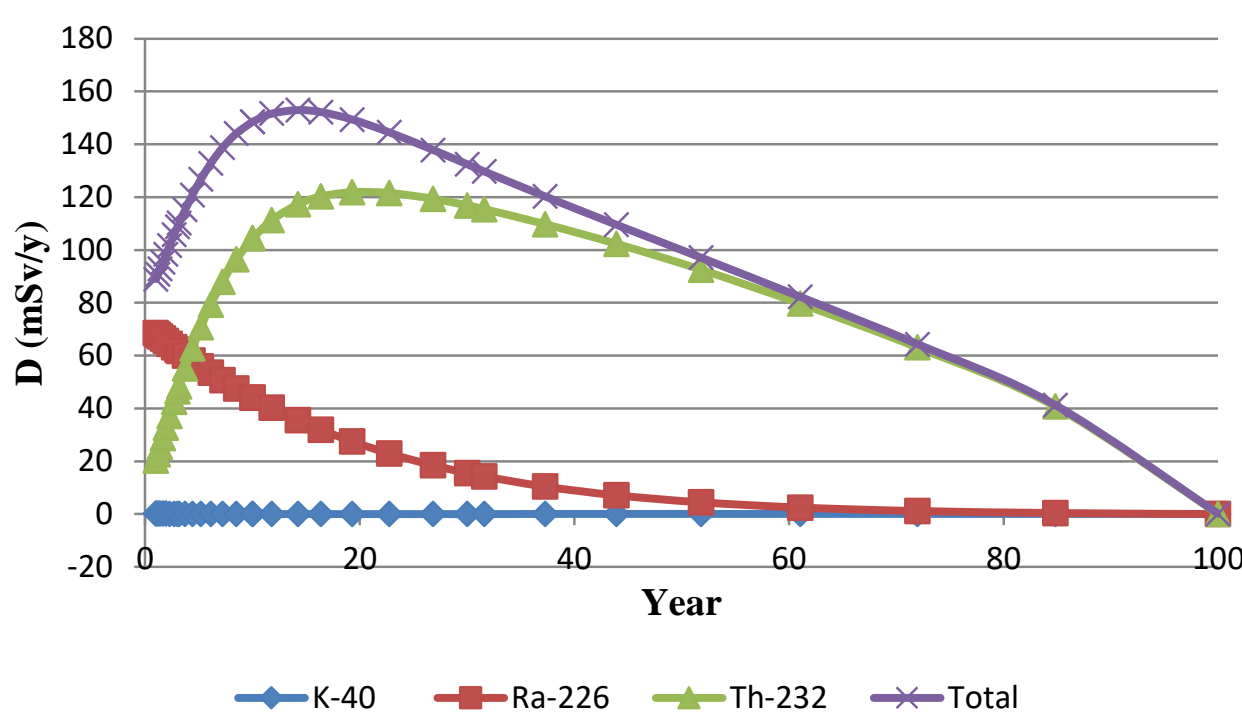

Fig (7): Summed total dose due to all nuclides and all pathways

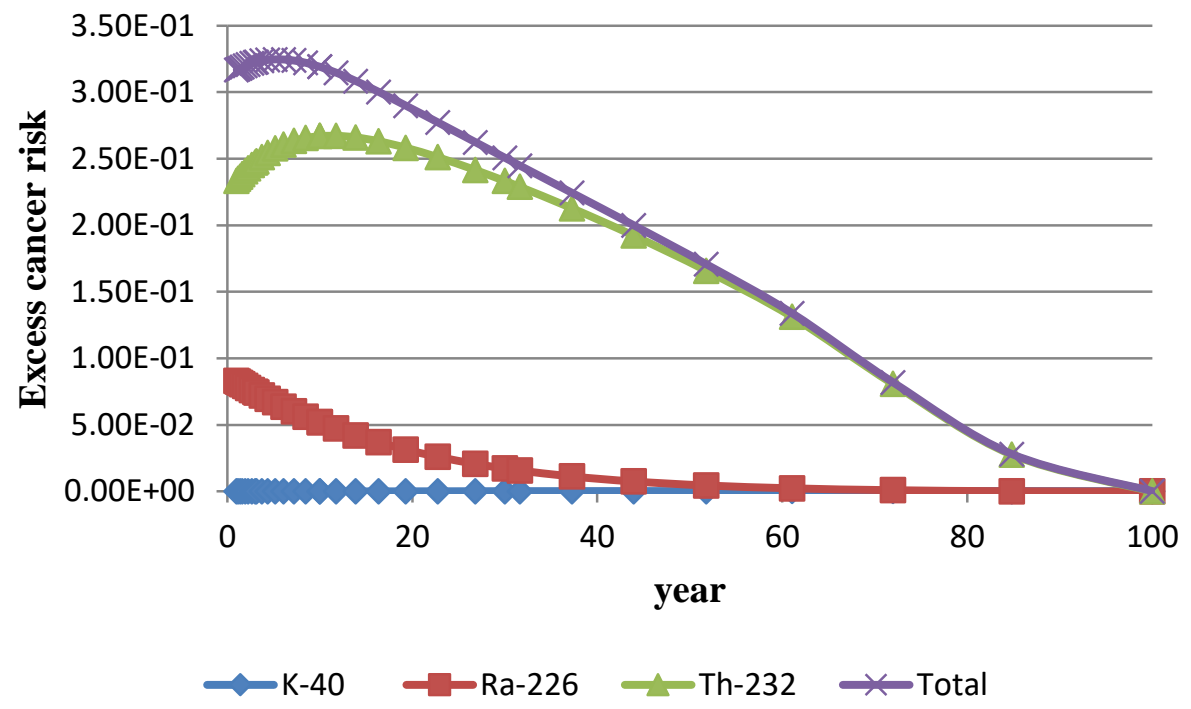

Fig (8):The excess cancer risk index due to all nuclides and all pathways

\section{References:}

1. Oliveira, E. P., Santelli, R. E and Cassella, R.J. (2005) Direct determination of lead in produced waters from petroleum exploration by electrothermalatomic absorption spectrometry X-ray fluorescence using Ir$\mathrm{W}$ permanent modifier combined with hydrofluoric acid, Anal Chim Acta, 545, 85-91.

2. Yu Liang, Yang Ning, Lulu Liao and Bin Yuan (2018) Special Focus on Produced Waterin Oil and Gas Fields: Origin Management, and Reinjection Practice, ch. 14, Formation Damage during Improved Oil Recovery. Elsevier Inc.
3. Azetsu-Scott K., Yeats P., Wohlgeschaffen G., et al. (2007) Precipitation of heavy metals in produced water: influence on contaminant transport and toxicity. Mar Environ Res, 63,146-67.

4.Kaur, G., Mandal, A. K, Nihlani, M. C., et al. (2009) Control of sulfidogenic bacteria in produced water from the Kathloni oilfield in northeast India.Int Biodeterior Biodegrad, 63, 51-5.

5. Fakhru'l-Razi A., Pendashteh, A., Abdullah, L. C., et al. (2009) Review of technologies for oil and gas 
produced water treatment. J Hazard Mater, 170, 530 551.

6. Othman,I. and Al-Masri,M. (2004) Disposal Strategy for NORM Waste Generated by the Syrian Oil Industry, Conference: The International Symposium on the Disposal of Low Activity Waste, Cordoba, Spain.

7. Desouky.O.S. and Morsi T. (2018) Evaluation the annual effective dose of the NORM decontamination workers during cleaning the oil and gas equipment, Arab J. Nucl. Sci. Appl., 51(4), 44-50.

8. Jerez Vegueria S. F., Godoy J. M., Miekeley N., et al. (2002) Environmental impact studies of barium and radium discharges by produced waters from the 'Bacia de Campos' oil-field offshore platforms, Brazil. J Environ Radioactivity,62, 29-38.

9. Landsberger,S. et al., (2013) Determination of 226Ra, $228 \mathrm{Ra}$ and $210 \mathrm{~Pb}$ in NORM products from oil and gas exploration: problems in activity underestimation due to the presence of metals and self-absorption of photons, J. Environ.Radioact.,125, 23-26.

10. Yu, K.N., Guan, Z.J., Stocks, M.J. and Young, E.C.(1992)The assessment of natural radiation dose in Egyptian population from radiocontaminated food after Chernobyl accident. In: El-Raey, E. (Ed.), Regional Symposium on Environmental Studies (UNAR). Alexandria, Egypt.

11. Baird, R.D., Merrell, G.B., Klein, R.B., Rogers, V.C. and Nielson, K.K.(1990) Management and Disposal Alternatives for NORM Wastes in Oil Production and Gas Plant Equipment, RAE-8837.2-1.prepared for American Petroleum Institute, Dallas, Texas (Rogers and Associates Engineering Corp, Salt Lake City, Nev).

12. Smith, K.P. (1992) An Overview of Naturally Occurring Radioactive Materials (NORM) in the Petroleum Industry; ANL/EAIS-7. U.S. Department of Energy, Argonne National Laboratory, Environmental Assessment and Information Sciences Division, Argonne, IL., December.

13. Al-Masri, M.S. and Suman, H. (2003) NORM waste in the oil and gas industry: the Syrian experience, Journal of Radio analytical and Nuclear Chemistry, 256, 159-162.

14. Mohsen, M., Ali, M., Hongtao Zhao, Zhongyu Li and Najeeb, N. M. Maglas(2019) Concentrations of TENORMs in the petroleum industry and their environmental and health effects. RSC Adv., 9,3920139229

15. UNSCEAR.(1998) Sources and effects of ionizing radiation. Report of the United Nations Scientific Committee on the Effects of Atomic Radiation to the general Assembly. New York, USA: United Nations.

16. Berekta, J., and Matthew, P. J. (1985) Natural radioactivity of Australian building materials, waste and by-products. Health Physics, 48, 87-95.
17. UNSCEAR. (2000) Ionizing radiation: Sources and biological effects. Report to the general assembly with scientific annexes. NewYork: United Nations.

18. Al-trabulsy, H. A., Khater, A. E. M., and Habbani, F. I. (2011) Radioactivity levels and radiological hazard indices at the Saudi coastline of the Gulf of Aqaba. Radiation Physics and Chemistry, 80, 343-348.

19. Ravikumar, P., and Somashekar, R. K., (2014) Determination of the radiation dose due to radon ingestion and inhalation. International Journal of Environmental Science and Technology, 11, 493-508.

20. Taskin, H., Karavus, M., Ay, P., Topuzoglu, A., Hidiroglu, S., and Karahan, G. (2009) Radionuclide concentrations in soil and lifetime cancer risk due to the gamma radioactivity in Kirklareli, Turkey. Journal of Environmental Radioactivity, 100, 49-53.

21. Senthilkumar,R.D.and Narayanaswamy,R. (2016) Assessment of radiological hazards in the industrial effluent disposed soil with statistical analyses. Journal of Radiation Research and Applied Sciences, 9, 449-456.

22. Arafa, W. (2004). Specific activity and hazards of granite samples collected from the Eastern desert of Egypt. Journal of Environmental Radioactivity, 75, 315-322.

23. Avwiri, G.O. and Ononugbo, C.P., (2011) Assessment of the naturally occurring radioactive material (NORM) content of hydrocarbon exploration and production activities in ogba/egbema/ndoni oil/gas field, rivers state, Nigeria. In: Proceedings of the 1st International Technology, Education and Environment Conference. African Society for Scientific Research, pp. 572-580.

24. Johnson, J.B., Bahadori, A.A. andEckerman, K.F., (2011) Response functions for computing absorbed dose to skeletal tissues from photon irradiation - an update. Phys. Med. Biol.56, 23472365.

25. Kurnaz, A., Kucukomeroglu, B., Keser, R., Okumusoglu, N. T.,Korkmaz, F., Karahan, G., et al. (2007) Determination of radioactivity levels and hazards of soil and sediment samplesin Firtina Valley (Rize, Turkey). Applied Radiation and Isotope, 65,1281-1289.

26. EC, European Commission, (1999) Radiological protection principles concerning the natural radioactivity of building materials. In: Radiation Protection 112, Direc-torate General Environment, Nuclear Safety and Civil Protection. European Commission, Luxembourg, Belgium.

27. EC, European Commission, (2000) Radiological protection principles concerning the natural radioactivity of building materials. In: Radiation Protection 112,Directorate-General Environment, Nuclear Safety and Civil Protection, Luxem-bourg, Belgium.

28. El Afifi, E.M., Shahr El-Din, A.M., Aglan, R.F., Borai, E.H. and Abo-Aly, M.M. (2017) Baseline 
evaluation for natural radioactivity level and radiological hazardous parameters associated with processing of high grade monazite. Regul.Toxicol. Pharmacol.89, 215-223.

29. O'Brien, K., and Sanna, R. (1976) The distribution of absorbed dose-rates in humans from exposure to environmental gamma rays. Health and Physics, 30(1), 71-78.

30. El-Gamal, A., Nasr, S., and El-Taher, A. (2007) Study of spatial distribution of natural radioactivity in the Upper Egypt Nile River sediments. Radiation Measurements, 42, 457-465.

31. Othman, M. H. and Hassan, H. B. (2013) Application of RESRAD Model to Assess Radiation Doses due to TE- NORM Accumulation in Evaporation Pond during Petroleum Production, Arab Journal of Nuclear Science and Applications, 46(2), 172-179. 